\title{
Methodology for Evaluation of POs and PEOs Achievement Level for Graduate Engineering Program
}

\author{
Ch. Ram Mohan ${ }^{1}$ and Dr. K. Venkateswar Rao ${ }^{2}$ \\ ${ }^{1}$ CVR College of Engineering, CSE Department \\ Email: chramohan@gmail.com \\ ${ }^{2}$ CVR College of Engineering, CSE Department \\ Email: kvenkat.cse@gmail.com
}

\begin{abstract}
The concept of cost effective and best quality service became a mantra for success of unaided Education Institutions in general and Technical Institutions in particular. Hence the processes that are being followed by these institutions are to be evaluated for the benefit of both the institutions and the Society. The Evaluation enables the institutions to rectify the lapses identified and adjust the process for continuously improving the quality of services. In this paper, a methodology for measuring the effectiveness of Technical Education through Program Educational Objectives and Program Outcomes is described. The formulated methodology is applied to graduate program in Computer Science and Engineering. The results so obtained are also described.
\end{abstract}

Index Terms-Program Outcomes Evaluation, Program Educational Objectives Evaluation

\section{I.INTRODUCTION}

Since the last few years, there has been much hue and cry about quality of higher education in India. The approach paper of the 12th Five Year Plan clearly argues that the focus should not only be on increased enrolment in higher education, but also on the improved quality of the expansion in higher education [1]. Accreditation and Ranking are two different forms of quality assurance or measurement [1]. Accreditation is to assure that quality of education, being offered by an institution, conforms to the well-defined standards set by the regulatory authority. National Board of Accreditation (NBA) [4] and National Assessment and Accreditation Council (NAAC) [5] are the two popular agencies in India for assessing the quality of education and accreditation of the institutions [1]. Accreditation is both a process and Status [3]. NBA, India has become the permanent signatory member of the Washington Accord on 13th June 2014 to get recognition for the quality of undergraduate engineering education offered in India [6].

The evaluation process by NBA involves Program educational objectives (PEOs) [2,8], Program outcomes (POs) [8], Course Outcomes [8] and mappings among them. PEOs are broad statements that describe the career and professional accomplishments that the program is preparing graduates to achieve $[2,8]$. As an example, statements about Employable, Professionalism, Interdisciplinary, Continuous Learning and Adaptability are PEOs. Educational Institutions follow standard processes to establish PEOs. POs are narrower statements that describe what students are expected to know and be able to do by the time of graduation [8]. These relate to the skills, knowledge, and behaviors that students acquire in their graduation through the program. A well-defined process is generally adapted to identify POs. COs are narrower statements that describe what students are expected to know and be able to do at the end of each course [8]. NBA provides Format for Preparing SelfAssessment Report [7] for Accreditation of UG Engineering Programs. It adapts well defined process [9] for Assessment and Accreditation of the Engineering Institutions based on the quality practices [10] followed by the Institution. A Methodology for Evaluation [2] of achievement of POs and PEO is described in this paper and it is applied to evaluate achievement levels of POs and PEOs for Graduate Computer Science and Engineering Program at CVR College of Engineering.

This paper is organized as follows. Introduction is described in section 1 . Section 2 briefs direct and indirect methods used in the evaluation. Computation methodology for evaluation of attainment level for POs is elaborated in Section 3. Methodology for PEOs achievement level computation is described in Section 4. The results of application of the methodology to Graduate Engineering Program in Computer Science and Engineering are provided as a case study in section 5. Section 6 describes Conclusions.

\section{Methods For Evaluation OF POS}

The program outcomes are assessed using direct and indirect methods of evaluation. The direct methods use marks and grades obtained in various courses, labs, seminars and projects that are done by the students in their graduate program. The indirect method is based on surveys conducted during and after their graduation. The weightage given to direct and indirect methods for calculating POs achievement levels is $70 \%$ and $30 \%$ respectively.

\section{A) Direct Methods}

The direct methods of evaluation use following information

- Course outcomes to Program outcomes mapping.

- Results of following exams for each course
○ Mid -1 examination (M1)
- Mid -2 examination (M2)
○ Mid -3 examination (M3)
- External Examination

- Results of Lab examinations for practical courses. 
- Internal Lab examination

- External Lab examination

\section{B) Indirect Methods}

The indirect methods of evaluation use the following information

- Course Level Surveys

○ Student Feedback (SF) survey

- Course End (CS) survey

- Program Outcome Level Surveys

○ Graduate Survey (GS)

- Alumni Survey (AS)

- Employer Survey (ES)

○ Parent Survey (PS)

\section{Methodology For PO Achievement Level Assessment}

Each Program Outcome Achievement Level (POx) is assessed using the following formula

Achievement Level $\left(P O_{x}\right)=$

Course Level Direct Component +

Course Level Indirect component $+(1)$

$\mathrm{PO}_{x}$ Level Indirect Component

The weightages given to Course level component, course level Indirect component and POx Level Indirect Component are $70 \%, 10 \%$ and $20 \%$ respectively.

The course level direct component is computed using course weight and contribution of that course in achieving the program outcome. Each program outcome has a set of courses that contribute towards its achievement.

The following are the formulae to compute the course level direct component and course level indirect component for particular program outcome Pox

$7 * \sum_{i=1}^{\text {Course level direct component }=}$ POx Acheivement level by course $i(2)$

Course level indirect component $=$

Student feedback survey component $(5 \%)+$

Course end survey Component (5\%)

The following is the formula to compute the PO level Indirect component for particular program outcome POx

POx Level Indirect component $=$

Graduate Survey Component (5\%)+

Alumni Survey component (5\%) +

Employer Survey component $(5 \%)+$

Parent Survey Component (5\%).

The "course weight" indicates the capability of the course in achieving a particular program outcome. The course weight value can be different for various program outcomes. It can be calculated for each course as follows
Using data in Course outcomes to Program outcomes mapping table generate data for the following table for each program outcome

TABLE -1

COURSE OutCOMES TO PROGRAM OUTCOMES MAPPING TABLE

\begin{tabular}{|c|c|c|c|c|c|}
\hline \multirow{2}{*}{ Course } & \multicolumn{3}{|c|}{ Impact of course on $\mathrm{PO}$} & \multirow{2}{*}{$\begin{array}{c}\text { Weighted } \\
\text { Average }\end{array}$} & \multirow{2}{*}{$\begin{array}{l}\text { Course } \\
\text { Weight }\end{array}$} \\
\hline & $\begin{array}{c}\text { No of } \\
\text { H's }\end{array}$ & $\begin{array}{c}\text { No of } \\
\text { M's }\end{array}$ & $\begin{array}{c}\text { No of } \\
\text { L's }\end{array}$ & & \\
\hline Course-1 & $\mathrm{a}$ & $\mathrm{b}$ & $\mathrm{c}$ & $(8 a+4 b+2 c) /(a+b+c)$ & \\
\hline & & & & & \\
\hline & & & & & \\
\hline
\end{tabular}

Weighted Average $=$

(8* no of H's $+4 *$ no of $M^{\prime}$ 's $+2 *$ no of $L$ 's)/(no of H's + no of M's + no of L's)

Weightage of $\mathrm{H}, \mathrm{M}$ and $\mathrm{L}$ are given as 8,4 and 2 respectively to reflect the variation in the impact of the course outcomes on specific program outcome.

Total Weighted Average $(W)=$ Sum of the weighted averages

Course Weight $=$

Weighted Average of the coursel

Total Weighted Average

The Program outcome achievement Level by Course i (Xi) on scale of 10 is computed as follows

$\begin{aligned} X i= & \{[0.1 *(S / P) \text { for } M 1]+[0.1 *(S / P) \text { for } M 2]+ \\ & {[0.1 *(S / P) \text { for } M 3]+[0.4 *(S / P) \text { for } E]\} * 10 }\end{aligned}$

$\mathrm{S}=$ Number of students Passed in the exam.

$\mathrm{P}=$ Number of students Participated in the exam.

M1, M2,M3, E are the mid-1, mid-2, mid-3 and end examinations respectively for course $i$.

The Program outcome achievement Level by Lab i (Li) on scale of 10 is computed as follows

$L i=\{[0.3 *(S / P)$ for $I]+[0.4 *(S / P)$ for $E]\} * 10$

(7)

$\mathrm{S}=$ Number of students Passed in the lab examination.

$\mathrm{P}=$ Number of students Participated in the lab examination. I, E are the internal and external examinations respectively for lab i.

Using formulas 5,6 and 7, Course level direct component in formula 2 can be computed

Student Feedback Survey Component can be computed for each program outcome using following methodology

A) Create The Following Table for Each PO, Say Pox 
TABLE -2

TABLE TO COMPUTE STUDENT FEEDBACK SURVEY

\begin{tabular}{|c|c|c|c|c|c|c|c|c|}
\hline \multirow{2}{*}{$\begin{array}{c}\text { Courses } \\
\text { for POx }\end{array}$} & \multicolumn{4}{|c|}{ Actual Values } & \multicolumn{5}{|c|}{ Normalized values } \\
\hline & H & M1 & M2 & L & H & M1 & M2 & L \\
\hline Course 1 & a & b & c & d & a1 & b1 & c1 & d1 \\
\hline Course 2 & & & & & & & & \\
\hline & & & & & & & & \\
\hline & & & & & & & & \\
\hline & & & & & & & & \\
\hline & & & & & & & & \\
\hline Course k & & & & & & & & \\
\hline
\end{tabular}

The actual values such as a, b, c, d for each course can be obtained from the feedback survey forms for that course.

$$
\begin{aligned}
& \text { Normalized value }=\quad(\text { Actual Value }) \\
& \text { sum of Actual Values)*100 } \\
& \text { Example : } \quad a 1=[a /(a+b+c+d)] * 100 \\
& b 1=[b /(a+b+c+d)]^{*} 100 \\
& \mathrm{c} 1=[\mathrm{c} /(\mathrm{a}+\mathrm{b}+\mathrm{c}+\mathrm{d})] * 100 \\
& \mathrm{~d} 1=[\mathrm{d} /(\mathrm{a}+\mathrm{b}+\mathrm{c}+\mathrm{d})] * 100
\end{aligned}
$$

B) Perform following Computations for POx

$$
\begin{aligned}
T=\Sigma H+ & \Sigma M 1+\Sigma M 2+\Sigma L \\
& =k^{*} 100 .
\end{aligned}
$$

Where $k$ is the number of courses for $P O x$

Contribution of $\Sigma \mathrm{H}$ in achieving $\mathrm{POx}=(\Sigma \mathrm{H} / \mathrm{T}) * 5 \rightarrow \mathrm{f} 1$

Contribution of $\Sigma \mathrm{M} 1$ in achieving $\mathrm{POx}=(\Sigma \mathrm{M} 1 / \mathrm{T}) * 4 \rightarrow \mathrm{f} 2$

Contribution of $\Sigma \mathrm{M} 2$ in achieving $\mathrm{POx}=(\Sigma \mathrm{M} 2 / \mathrm{T}) * 2 \rightarrow \mathrm{f} 3$

Contribution of $\Sigma \mathrm{L}$ in achieving $\mathrm{POx}=(\Sigma \mathrm{L} / \mathrm{T})^{*} 1 \rightarrow \mathrm{f} 4$

Feedback survey component for $P O x=f 1+f 2+f 3+f 4$ (8)

Similarly, Course End Survey Component can be computed for each program outcome.

C) Create the following table for each PO, say Pox TABLE - 3

TABLE TO COMPUTE COURSE END SURVEY

\begin{tabular}{|c|c|c|c|c|c|c|c|c|}
\hline \multirow{2}{*}{$\begin{array}{c}\text { Course } \\
\text { for POx }\end{array}$} & \multicolumn{3}{|c|}{ Actual Values } & \multicolumn{5}{c|}{ Normalized values } \\
\cline { 2 - 9 } & H & M1 & M2 & L & H & M1 & M2 & L \\
\hline Course 1 & a & b & c & d & a1 & b1 & c1 & d1 \\
\hline Course 2 & & & & & & & & \\
\hline & & & & & & & & \\
\hline & & & & & & & & \\
\hline & & & & & & & & \\
\hline & & & & & & & & \\
\hline Course k & & & & & & & & \\
\hline
\end{tabular}

The actual values such as a, b, c, d for each course can be obtained from the course end surveyforms for that course.

Normalized value $=($ Actual Value $)$ sum of Actual Values)*100

$$
\text { Example : } \quad \begin{aligned}
& \mathrm{a} 1=[\mathrm{a} /(\mathrm{a}+\mathrm{b}+\mathrm{c}+\mathrm{d})]^{*} 100 \\
& \mathrm{~b} 1=[\mathrm{b} /(\mathrm{a}+\mathrm{b}+\mathrm{c}+\mathrm{d})]^{* 100} \\
& \mathrm{c} 1=[\mathrm{c} /(\mathrm{a}+\mathrm{b}+\mathrm{c}+\mathrm{d})]^{*} 100 \\
& \mathrm{~d} 1=[\mathrm{d} /(\mathrm{a}+\mathrm{b}+\mathrm{c}+\mathrm{d})]^{* 100}
\end{aligned}
$$

D) Perform following Computations for POx

$$
\begin{aligned}
T=\Sigma H+ & \Sigma M 1+\Sigma M 2+\Sigma L \\
& =k^{*} 100 .
\end{aligned}
$$

Where $k$ is the number of courses for POx

\begin{tabular}{|c|c|c|c|c|c|c|c|c|}
\hline \multirow{2}{*}{$\begin{array}{l}\text { Survey for } \\
\text { POx }\end{array}$} & \multicolumn{4}{|c|}{ Actual Values } & \multicolumn{4}{|c|}{ Normalized values } \\
\hline & $\mathbf{H}$ & M1 & M2 & $\mathbf{L}$ & $\mathbf{H}$ & M1 & M2 & $\mathbf{L}$ \\
\hline $\begin{array}{c}\text { Graduate } \\
\text { Survey(GS) }\end{array}$ & $\mathrm{a}$ & b & $\mathrm{c}$ & $\mathrm{d}$ & $\mathrm{a} 1$ & b1 & $\mathrm{c} 1$ & d1 \\
\hline $\begin{array}{c}\text { Alumni } \\
\text { Survey (AS) }\end{array}$ & & & & & & & & \\
\hline $\begin{array}{c}\text { Employer } \\
\text { Survey (ES) }\end{array}$ & & & & & & & & \\
\hline $\begin{array}{c}\text { Parent } \\
\text { Survey (PS) }\end{array}$ & & & & & & & & \\
\hline
\end{tabular}

Contribution of $\Sigma \mathrm{H}$ in achieving $\mathrm{POx}=(\Sigma \mathrm{H} / \mathrm{T}) * 5 \rightarrow \mathrm{f} 1$ Contribution of $\Sigma \mathrm{M} 1$ in achieving $\mathrm{POx}=(\Sigma \mathrm{M} 1 / \mathrm{T}) * 4 \rightarrow \mathrm{f} 2$ Contribution of $\Sigma \mathrm{M} 2$ in achieving POx $=(\Sigma \mathrm{M} 2 / \mathrm{T}) * 2 \rightarrow \mathrm{f} 3$ Contribution of $\Sigma \mathrm{L}$ in achieving $\mathrm{POx}=(\Sigma \mathrm{L} / \mathrm{T})^{*} 1 \rightarrow \mathrm{f} 4$

Course end survey component for POx $=f 1+f 2+f 3+f 4$ (9)

Using formulas 8 and 9 course level indirect component in formula 3 can be computed

Indirect Level Component for each PO can be computed using the following procedure

E) Create The Following Table For Each PO, Say POx

TABLE -4

TABLE TO COMPUTE INDIRECT LEVEL COMPONENT

The actual values such as a, b, c, d for each survey can be obtained from the respective survey forms for that Program Outcome.

$$
\text { Normalized value }=\begin{gathered}
(\text { Actual Value } / \\
\text { sum of Actual Values }) * 100
\end{gathered}
$$

Example : $\quad \mathrm{a} 1=[\mathrm{a} /(\mathrm{a}+\mathrm{b}+\mathrm{c}+\mathrm{d})]^{*} 100$

$\mathrm{b} 1=[\mathrm{b} /(\mathrm{a}+\mathrm{b}+\mathrm{c}+\mathrm{d})] * 100$

$\mathrm{c} 1=[\mathrm{c} /(\mathrm{a}+\mathrm{b}+\mathrm{c}+\mathrm{d})]^{*} 100$

$\mathrm{d} 1=[\mathrm{d} /(\mathrm{a}+\mathrm{b}+\mathrm{c}+\mathrm{d})] * 100$ 
F) Perform following Computations for POx

$$
\begin{gathered}
T=\Sigma H+\Sigma M 1+\Sigma M 2+\Sigma L \\
=4 * 100 .
\end{gathered}
$$

Contribution of $\Sigma \mathrm{H}$ in achieving $\mathrm{POx}=(\Sigma \mathrm{H} / \mathrm{T}) * 20 \rightarrow \mathrm{f} 1$ Contribution of $\Sigma \mathrm{M} 1$ in achieving $\mathrm{POx}=$ $(\Sigma \mathrm{M} 1 / \mathrm{T}) * 15 \rightarrow \mathrm{f} 2$

Contribution of $\Sigma \mathrm{M} 2$ in achieving $\mathrm{POx}=$ $(\Sigma \mathrm{M} 2 / \mathrm{T})^{*} 10 \rightarrow \mathrm{f} 3$

Contribution of $\Sigma \mathrm{L}$ in achieving $\mathrm{POx}=(\Sigma \mathrm{L} / \mathrm{T}) * 5 \rightarrow \mathrm{f} 4$

POx Level Indirect Component (in formula 4$)=$ $f 1+f 2+f 3+f 4$

(10)

Now POx Achievement Level in formula 1 can be computed using the results of formulas 2, 3 and 4 .

The above methodology for computing PO achievement level can be applied for all Program Outcomes.

\section{Methodology For PEO Achievement level Assessment}

The Program Educational Objectives are assessed using the information from the following tables.

- $\quad$ PEO's Vs PO's mapping table.

- $\quad$ PEO's Vs Courses mapping table.

- $\quad$ PO's Vs Courses mapping table.

Using information from the above tables, create following

\begin{tabular}{|c|c|c|c|c|c|c|c|}
\hline \multirow[t]{2}{*}{ PO's } & \multirow[t]{2}{*}{ Subjects } & \multirow{2}{*}{$\begin{array}{c}\text { Impact } \\
\text { of } \\
\text { Subject } \\
\text { on PEOx }\end{array}$} & \multicolumn{3}{|c|}{$\begin{array}{l}\text { Total } \\
\text { Count }\end{array}$} & \multirow{2}{*}{$\begin{array}{l}\text { Weighted } \\
\text { Average }\end{array}$} & \multirow{2}{*}{$\begin{array}{c}\text { PO } \\
\text { Weight }\end{array}$} \\
\hline & & & $\mathbf{H}$ & M & $\mathbf{L}$ & & \\
\hline \multirow{5}{*}{ PO-1 } & Subject-1 & $\mathrm{H}$ & $\mathrm{a}$ & b & $\mathrm{c}$ & \multirow{5}{*}{$\begin{array}{c}W 1=(8 a+4 b \\
+2 c) /(a+b+c \\
)\end{array}$} & \multirow{5}{*}{$\mathrm{W} 1 / \mathrm{G}$} \\
\hline & Subject-2 & $\mathrm{M}$ & & & & & \\
\hline & & & & & & & \\
\hline & . & & & & & & \\
\hline & Subject-k & $\mathrm{L}$ & & & & & \\
\hline \multirow{5}{*}{ PO-2 } & Subject-1 & $\mathrm{H}$ & $\mathrm{p}$ & $\mathrm{q}$ & $\mathrm{r}$ & \multirow{5}{*}{$\begin{array}{l}\mathrm{W} 2=(8 \mathrm{p}+4 \mathrm{q} \\
+2 \mathrm{r}) /(\mathrm{p}+\mathrm{q}+\mathrm{r})\end{array}$} & \multirow{5}{*}{ W2/G } \\
\hline & Subject-2 & $\mathrm{M}$ & & & & & \\
\hline & . & & & & & & \\
\hline & & & & & & & \\
\hline & Subiect-n & I & & & & & \\
\hline & & & & & & & \\
\hline & & & & & & & \\
\hline & & & 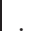 & & & & \\
\hline \multirow{5}{*}{ PO-12 } & Subject-1 & $\mathrm{H}$ & $\mathrm{x}$ & $\mathrm{y}$ & $\mathrm{Z}$ & \multirow{5}{*}{$\begin{array}{c}\mathrm{W} 12=(8 \mathrm{x}+4 \\
\mathrm{y}+2 \mathrm{z}) /(\mathrm{x}+\mathrm{y}+ \\
\mathrm{z})\end{array}$} & \multirow{5}{*}{$\mathrm{W} 12 / \mathrm{G}$} \\
\hline & Subject-2 & $\mathrm{M}$ & & & & & \\
\hline & . & & & & & & \\
\hline & . & & & & & & \\
\hline & Subject-m & $\mathrm{L}$ & & & & & \\
\hline
\end{tabular}
table for each PEO say PEOx

$\mathrm{G}=\mathrm{W} 1+\mathrm{W} 2+\ldots+\mathrm{W} 12$
Using PO weight column from the above table and PO achievement level for all PO's, the PEOx Achievement level can be computed using the following formula

PEOX Achiovement Level $=\sum_{i=1}^{12}$ POi Weight for PEOX * POi Achiovement Level

\section{CASe Study}

As a case study, the methodology described is applied to evaluate achievement levels of POs and PEOs for graduate Computer science and engineering program at CVR College of Engineering. Five PEOs, Twelve POs, 79 Courses and Outcomes for each Corse were identified through well defined process [11]. Mappings among PEOs, POs, Courses and COs were done [11]. The data required to compute direct and indirect level components are collected [11]for three batches of Computer Science and Engineering graduates, 2009-2013, 2010-2014, 2011-2015. Summarized Results [11] obtained after evaluation of POs, PEOs for the three batches of the graduates are given above. The achievement level of PEOs are the indicators to show potential of the graduates to succeed in their career. These values need to be validated through collection and processing of the relevant data from concerned alumni for few years after three years of their graduation.

\section{PO Acheivement -2009 Batch,2010 Batch and 2011 Batch}
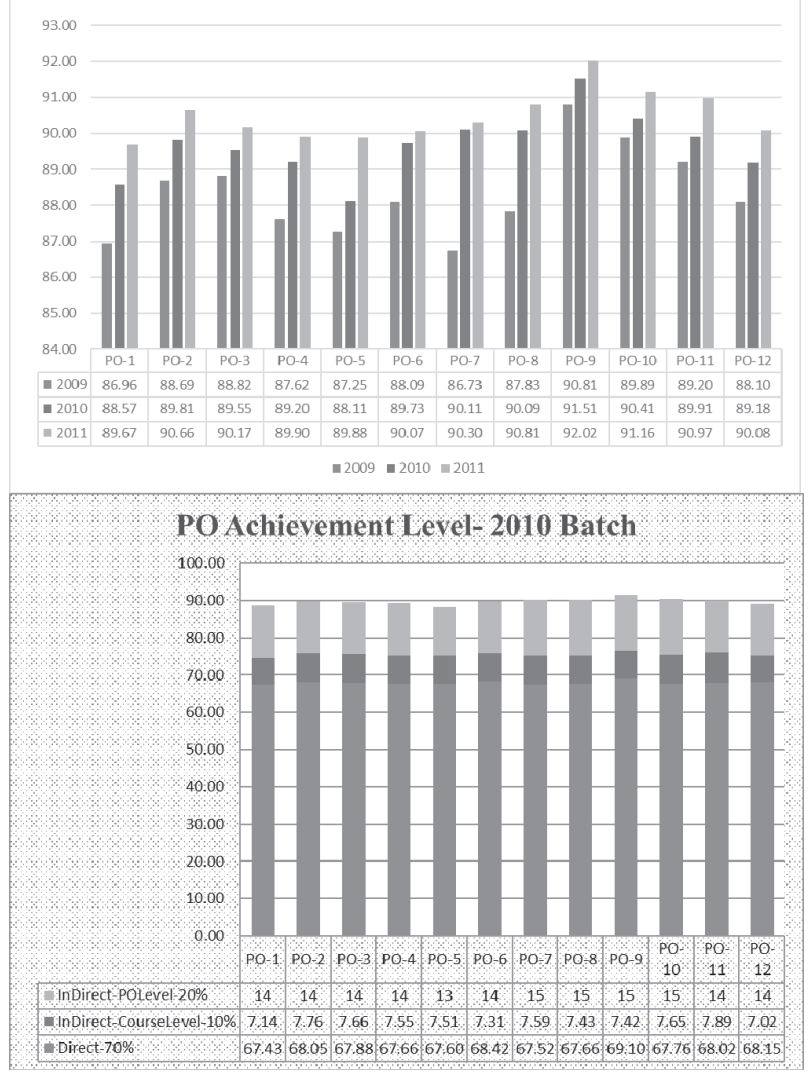
Achievement Levels Of Programme Educational Objectives : 2013,2014 and 2015.

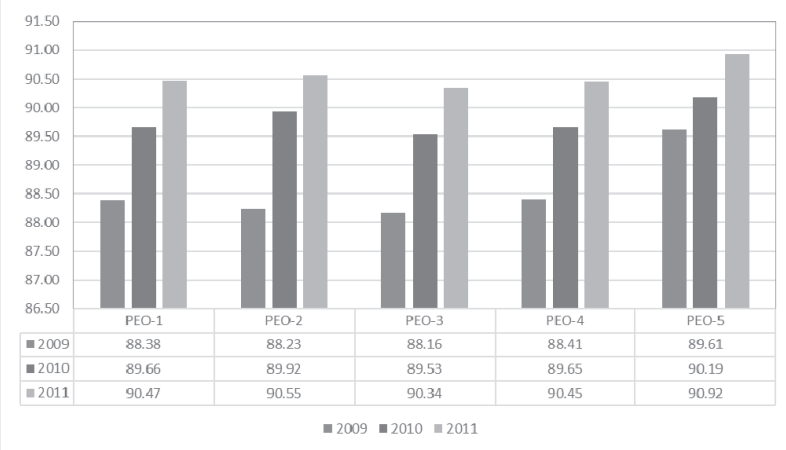

\section{Conclusion}

In view of expansion of engineering education institutions, it is desirable to have a methodology to assess the quality parameters for sustaining and continuously improving the quality of education. The methodology proposed in this paper is a step towards assessing quality parameters such as program outcomes and program educational objectives. The methodology has incorporated both direct and indirect tools of evaluation. The marks obtained in a course are considered as achievement level of the course outcome. The methodology is well elaborated and applied to graduate program in computer science and engineering. The results shows that there is continues improvement in both program outcomes and program educational objectives for three batches of graduate computer science and engineering students. This methodology has assumed that mapping of course outcomes to program outcomes, courses to program educational objectives and program outcomes to program educational objectives are done correctly. This methodology can be enhanced to include evaluation of course outcomes by establishing mapping of course learning objectives to course outcomes and assessing the level of achievement of course outcomes based on performance of the students in relevant experiments done and questions answered during regular evaluation when the course is offered to them.

\section{REFERENCES}

[1] Emon Nandi and Saumen Chattopadhyay, "Quality, Accreditation and Global University Ranking Issues before Indian Higher Education”, India Infrastructure Report 2012, PP 167-177

[2] ABET, "CRITERIA FOR ACCREDITING

ENGINEERING PROGRAMS”, November, 2014.

[3] Council for Higher Education Accreditation (CHEA), USA "The Value of Accreditation, 2010.

[4] National Board of Accreditation, http://www.nbaind.org/views/Home.aspx

[5] National Assessment and Accreditation Council, http://www.naac.gov.in/

[6] NBA-Washington Accord, http://www.nbaind.org/En/1033-washington-accord.aspx
[7] NBA Self Assessment Report Format, http://www.nbaind.org/Files/ug-sar-tier-i-final-ver-1.0.pdf

[8] NBA Accreditation Manual, http://www.nbaind.org/Files/UG\%20$\% 20$ Tier\%20I\%20Manual.pdf

[9] NBA Accreditation Process, http://www.nbaind.org/En/1053-nba-accreditationprocess.aspx

[10] NBA Accreditation Parameters Criteria and Processes, http://www.nbaind.org/En/1051-nbas-accreditationparameters-criteria-and-processes.aspx

[11] CVR College of Engineering, Updated Self Assessment Report NBA_SAR_CSE_2015.doc, 2015 